九州大学学術情報リポジトリ

Kyushu University Institutional Repository

Ecological Studies on Formica yessensis Forel, with Special Reference to Its Effectiveness as a Biological Control Agent of the Pine Caterpillar Moth in Korea : IV. Artificial Colonization of Nests

Kim, Chang Hyo

Division of Insect Natural Enemies, Institute of Biological Control, Faculty of Agriculture, Kyushu University

Murakami, Yozo

Division of Insect Natural Enemies, Institute of Biological Control, Faculty of Agriculture, Kyushu University

https://doi.org/10.5109/23737

出版情報 : 九州大学大学院農学研究院紀要. 26 (1)，pp. 39-44，1981-10. Kyushu University バージョン：

権利関係 : 


\title{
Ecological Studies on Formica yessensis Forel, with Special Reference to Its Effectiveness as a Biological Control Agent of the Pine Caterpillar Moth in Korea
}

\author{
IV. Artificial Colonization of Nests* \\ Chang Hyo Kim** and Yôzô Murakami \\ Division of Insect Natural Enemies, Institute of Biological Control. \\ Faculty of Agriculture, Kyushu University 46-13. Fukuoka 812
}

(Received June 16. 1981)

\begin{abstract}
Two experiments of artificial colonization of Formica yessensis were conducted in several red pine stands of Gyeongsang-Nam-Do, Korea in 1972 and 1977. The ant easily established in forests growing 10 to 20-year-old red pine trees at a relatively high density but admitting sunlight to the forest floor, harbouring much bare grounds and long graminaceous grasses. The ant favours soils with much organic material and rather high moisture content but not wet excessively.
\end{abstract}

\section{INTRODUCTION}

Several red wood ants have been considered as outstanding predators capable of destroying large quantities of forest pests and maintaining their populations in equilibrium in European forests. Out of eight species reported in central Europe, Formica polyctena (Förster), the most valuable species, can easily be colonized and has received much attention by German entomologists due to its outstanding aggressivity and its ability to develop large colonial populations and to forage over extensive areas. Formica lugubris (Zett.) is also aggressive, forms colonies of large nests and maintains extensive foraging areas. This species has been studied in Italy and has been successfully transplanted from northern Italy to the Apennines and the island of Sardinia, and also introduced to eastern Canada (Adlung, 1966; Finnegan, 1975).

Since it has been generally believed that the injury by the pine caterpillar moth, Dendrolimus spectabilis Butler is extremely low in pine forests inhabited by Formica (Formica) yessensis Forel (Kim and Murakami, 1980 a), the senior author considered the artificial transplantation of the ant nests to forests not inhabited by the ant should be recommended on the aspect of biological control of the moth. F. yessensis is a polydomous (several nests often stand closely nearby and interconnected by the drifting of inhabitants) and a polygynous (one nest contains many queens) species (Ito, 1973; Kim and Murakami,

* Presented at the XVI International Congress of Entomology, Kyoto August 3-9, 1980.

** Present address : College of Agriculture, Gyeongsang National University, Jinju 620, Korea. 
1980 b). These peculiarity of the ant may facilitate the artificial colonization of nests successfully as in European $F$. polyctena and $F$. lugubris. The present paper refers to two experiments of the transplantation of ant colonies conducted in several red pine forest stands in the Jinju district, GyeongsangNam-Do, Korea.

\section{MATERIALS AND METHODS}

The first experiment was performed on May 20, 1972 in three pine stands at Munsan, Jinyang-gun (Stations B, C and D) and one stand at Gahodong, Jinju City (Station E). The population of $F$. yessensis for transplantation was collected from a red pine stand at Jinseung, Jinyang-gun (Station A, Kim and Murakami, 1981). For each colony, approximately 4,000 to 6,000 worker ants and 5 mated queens were put in a zinc box or a cloth bag with nesting material, and transported to the experimental areas. In each area 20 colonies were released at intervals of $10 \mathrm{~m}$. Until 1975 the number of nests were counted in April, August and November.

The second experiment was conducted on May 2, 1977 in four stations F, G, H and I at Jyeungchon, Jinyang-gun. The ants were collected from $a$ red pine stand at Sanam, Sacheun-gun where they occurred naturally. In each station, 10 colonies were liberated at intervals of $10 \mathrm{~m}$. After transplantation, the number of nests established was counted every month.

The forest composition of these experimental stations was as follows : Station B-thick plantation of 10 to 30 -year-old red pine trees, with graminaceous grasses (Arundinella hirta Tanaka, Cymbopogon tortilis var. Goeringii Handmazz, Eulalia speciosa Kuntze, Themeda triandra subsp. japonica Tanaka and Zoisia japonica Steud) at the lower and middle zones of the slope; the slope approximately $3,000 \mathrm{~m}^{2}$ with $10-15^{\circ}$ in gradient. Station C-sparse plantation of 10 to 20 -yearold red pine trees, with graminaceous grasses at the lower zone, scattering with Robinia pseudo-Acasia L. ; the slope approximately $2,500 \mathrm{~m}^{2}$ with $10-15$ " in gradient. Station D-sparse plantation of 30 to 40 -year-old red pine trees, with sparse graminaceous grasses and $R$. pseudo-Acasia; the slope approximately 2,000 $\mathrm{m}^{2}$ with 15-30" in gradient. Station E-sparse plantation of 10 to 15year-old red pine trees, with sparse graminaceous grasses; the slope approximately $1,000 \mathrm{~m}^{2}$ with $10-15$ " in gradient. Station F-sparse plantation of 10 to 25-year-old red pine trees with similar plant composition as the Station A (Kim and Murakami, 1981), a forest stand inhabited by the ant; formerly inhabited by the ants but exterminated by artificial cause 10 or more years previously; the slope approximately $3,000 \mathrm{~m}^{2}$ with $10-20$ " in gradient. Station G-thick plantation of 10 to 30 -year-old red pine trees, with sparse graminaceous grasses (C. tortilis var. Goeringii, E. speciosa and Z.japonica); the slope approximately 2,200 $\mathrm{m}^{2}$ with $20-25^{\circ}$ in gradient. Station $\mathrm{H}$-sparse plantation of 10 to 15 -year-old red pine trees, with sparse $E$. speciosa on the floor; the slope approximately $2,500 \mathrm{~m}^{2}$ with $10-20$ " in gradient. Station I-sparse plantation of 20 to 30 -yearold red pine trees, with sparse T. triandra japonica and C. tortilis var. Goeringii on the floor; the slope approximately $2,400 \mathrm{~m}^{2}$ with $10-15$ " in gradient. 
In order to determine the factors affecting artificial colonization of nests, chemical and physical properties of soils in a natural habitat (Station A) and experimental stations were examined. The chemical analysis was conducted with soil samples collected from the natural habitat and the experimental stations B, C, D, E, F, G, H and I, in July 1973 for Stations A to E, and in April 1977 for Stations F to I. The physica analysis was carried out only with soil samples

Table 1. Results of the soil chemical analysis in a natural habitat of $F$. yessensis (Station A) and in the experimental stations of artificial colonization of nests (Stations B-I).

\begin{tabular}{|c|c|c|c|c|c|c|}
\hline \multirow[b]{2}{*}{ Station } & \multirow{2}{*}{$\begin{array}{l}\text { Depth } \\
(\mathbf{c m})\end{array}$} & \multirow[b]{2}{*}{$\mathrm{pH}$} & \multicolumn{2}{|c|}{ Exchangeable } & \multirow{2}{*}{$\begin{array}{c}\text { Organic } \\
\text { mat. } \\
(\%) \\
\end{array}$} & \multirow{2}{*}{$\begin{array}{c}\text { Moisture } \\
(\%)\end{array}$} \\
\hline & & & $\mathrm{Ca}$ & $\mathrm{Mg}$ & & \\
\hline A & $\begin{array}{r}0-10 \\
10-20 \\
20-40 \\
40-60 \\
60-80\end{array}$ & $\begin{array}{l}5.1 \\
5.3 \\
5.2 \\
5.2 \\
5.3\end{array}$ & $\begin{array}{l}0.86 \\
0.53 \\
0.60 \\
0.80 \\
0.65\end{array}$ & $\begin{array}{l}0.96 \\
1.30 \\
1.20 \\
2.00 \\
2.10\end{array}$ & $\begin{array}{l}2.4 \\
1.9 \\
2.2 \\
0: 7 \\
0.6\end{array}$ & $\begin{array}{l}19.6 \\
18.5 \\
18.2 \\
18.0 \\
19.7\end{array}$ \\
\hline B & $\begin{array}{c}\mathrm{n}-10 \\
10-20 \\
20-40 \\
40-60\end{array}$ & $\begin{array}{l}5.2 \\
5.2 \\
5.1 \\
5.1\end{array}$ & $\begin{array}{l}3.56 \\
3.25 \\
3.23 \\
2.23\end{array}$ & $\begin{array}{l}\text { 3. } 16 \\
\text { 3.40 } \\
3.58 \\
4.20\end{array}$ & $\begin{array}{l}1.8 \\
1.4 \\
0.9 \\
0.8\end{array}$ & $\begin{array}{l}24.8 \\
13.9 \\
16.9 \\
18.7\end{array}$ \\
\hline c & $\begin{array}{r}0-10 \\
10-20 \\
20-40 \\
40-60\end{array}$ & $\begin{array}{l}5.6 \\
5.4 \\
5.8 \\
5.8\end{array}$ & $\begin{array}{l}4.80 \\
4.20 \\
4.40 \\
5.95\end{array}$ & $\begin{array}{l}3.30 \\
2.90 \\
4.10 \\
5.40\end{array}$ & $\begin{array}{l}1.8 \\
1.1 \\
0.5 \\
0.5\end{array}$ & $\begin{array}{l}20.4 \\
18.4 \\
18.9 \\
21.2\end{array}$ \\
\hline $\mathrm{D}$ & $\begin{array}{r}0-10 \\
10-20 \\
20-40\end{array}$ & $\begin{array}{l}5.4 \\
5.5 \\
5.4\end{array}$ & $\begin{array}{l}4.10 \\
1.90 \\
2.10\end{array}$ & $\begin{array}{l}2.30 \\
2.40 \\
3.10\end{array}$ & $\begin{array}{l}2.3 \\
2.0 \\
1.4\end{array}$ & $\begin{array}{l}20.3 \\
20.4 \\
19.3\end{array}$ \\
\hline $\mathrm{E}$ & $\begin{array}{r}0-10 \\
10-20\end{array}$ & $\begin{array}{l}5.3 \\
5.2\end{array}$ & $\begin{array}{l}4.50 \\
3.30\end{array}$ & $\begin{array}{l}1.30 \\
1.40\end{array}$ & $\begin{array}{l}0.5 \\
0.6\end{array}$ & $\begin{array}{r}9.3 \\
12.6\end{array}$ \\
\hline $\mathrm{F}$ & $\begin{array}{r}0-10 \\
10-20 \\
20-30 \\
30-40 \\
40-50 \\
50-60 \\
60-70 \\
70-80\end{array}$ & $\begin{array}{l}5.5 \\
5.5 \\
5.5 \\
5.5 \\
5.5 \\
5.7 \\
5: 6 \\
5.6\end{array}$ & $\begin{array}{l}3.30 \\
3,13 \\
3.93 \\
4.43 \\
3.73 \\
4.37 \\
4.53 \\
4.85\end{array}$ & $\begin{array}{l}1.30 \\
1.15 \\
1.60 \\
1.93 \\
2.10 \\
1.87 \\
2.53 \\
1.65\end{array}$ & $\begin{array}{l}2.2 \\
1.3 \\
1.1 \\
1.0 \\
1.0 \\
1.0 \\
0.9 \\
0.9\end{array}$ & $\begin{array}{l}26.5 \\
26.4 \\
30.1 \\
34.5 \\
34.5 \\
51.0 \\
40.3 \\
37.7\end{array}$ \\
\hline G & $\begin{array}{r}0-10 \\
10-20 \\
20-30 \\
30-40 \\
40-50 \\
50-60\end{array}$ & $\begin{array}{l}5.3 \\
5.3 \\
5.1 \\
5.2 \\
5.3 \\
5.5\end{array}$ & $\begin{array}{l}2.03 \\
1.28 \\
1.57 \\
1.30 \\
1.97 \\
5.50\end{array}$ & $\begin{array}{l}0.73 \\
0.67 \\
0.75 \\
0.60 \\
1.37 \\
0.60\end{array}$ & $\begin{array}{l}2.0 \\
1.3 \\
1.2 \\
1.0 \\
0.9 \\
0.5\end{array}$ & $\begin{array}{l}20.2 \\
23.7 \\
24.2 \\
26.3 \\
26.2 \\
30.9\end{array}$ \\
\hline $\mathrm{H}$ & $\begin{array}{r}0-10 \\
10-20 \\
20-30 \\
30-40 \\
40-50 \\
50-60\end{array}$ & $\begin{array}{l}5.5 \\
5.4 \\
5.3 \\
5.5 \\
5.5 \\
5.7\end{array}$ & $\begin{array}{l}2.33 \\
1.80 \\
2.03 \\
2.63 \\
3.57 \\
2.50\end{array}$ & $\begin{array}{l}0.77 \\
0.77 \\
1.37 \\
1.37 \\
0.63 \\
0.85\end{array}$ & $\begin{array}{l}1.5 \\
1.2 \\
1.0 \\
0.5 \\
0.6 \\
0.8\end{array}$ & $\begin{array}{l}19.1 \\
19.0 \\
19.9 \\
21.1 \\
21.6 \\
26.6\end{array}$ \\
\hline I & $\begin{array}{r}0-10 \\
\text { IO-20 } \\
20-30 \\
30-40 \\
40-50\end{array}$ & $\begin{array}{l}5.6 \\
5.5 \\
5.7 \\
5.8 \\
5.6\end{array}$ & $\begin{array}{l}4.40 \\
4.17 \\
6.60 \\
6.45 \\
4.30\end{array}$ & $\begin{array}{l}2.40 \\
2.67 \\
4.95 \\
5.85 \\
3.30\end{array}$ & $\begin{array}{l}2.0 \\
1.8 \\
1.1 \\
0.8 \\
0.7\end{array}$ & $\begin{array}{l}16.0 \\
20.3 \\
32.8 \\
34.8 \\
34.7\end{array}$ \\
\hline
\end{tabular}


Table 2. Results of the soil physical analysis in a natural habitat of F.yessensis (Station A) and in the experimental stations of artificial colonization of nests (Stations B-E).

\begin{tabular}{|c|c|c|c|c|c|c|}
\hline Station & $\begin{array}{l}\text { Depth } \\
(\mathrm{cm})\end{array}$ & $\begin{array}{c}\text { Coarse } \\
\text { sand } \\
(0)\end{array}$ & $\begin{array}{c}\text { Fine } \\
\text { sand } \\
(\%)\end{array}$ & $\begin{array}{l}\text { Silt } \\
(\mathscr{O})\end{array}$ & $\begin{array}{l}\text { Clay } \\
(\mathscr{0})\end{array}$ & Soil texture \\
\hline A & $\begin{array}{r}\text { O-10 } \\
20-40\end{array}$ & $\begin{array}{l}25.75 \\
12.25\end{array}$ & $\begin{array}{l}23.25 \\
33.75 \\
29.90\end{array}$ & $\begin{array}{l}29.25 \\
30.75\end{array}$ & $\begin{array}{l}21.75 \\
23.25\end{array}$ & $\begin{array}{ll}\text { Loamy } & \text { soil } \\
\text { Loamy } & \text { soil }\end{array}$ \\
\hline B & $\begin{array}{c}\text { O-10 } \\
20-40\end{array}$ & $\begin{array}{l}34.25 \\
17.60\end{array}$ & 17.50 & $\begin{array}{r}3.10 \\
35.70\end{array}$ & $\begin{array}{l}32.75 \\
29.20\end{array}$ & $\begin{array}{l}\text { Sandy clay } \\
\text { Light clay }\end{array}$ \\
\hline $\mathrm{C}$ & $\mathrm{O}-10$ & 20.70 & 29.00 & 23.60 & 26.70 & Clay loam \\
\hline $\mathrm{D}$ & O-10 & 47.60 & 15.45 & 10.95 & 26.00 & Sandy clay \\
\hline $\mathrm{E}$ & $\mathrm{O}-10$ & 53.20 & 18.50 & 18.10 & 10.20 & Sandy loam \\
\hline
\end{tabular}

collected from Stations A to E. The results are shown in Tables 1 and 2 .

\section{RESULTS AND DISCUSSION}

The results of the first experiment are shown in Fig. 1. In Stations B, C and $\mathrm{D}$, the number of nests was maintained at approximately 60 for the first two years, then it decreased to the 20 to 40 level. The following year the ants were considered well established. However, in Station E they were not established. In order to determine the reasons why the ants were not established in the station, the authors compared the soil between experimental stations (Tables 1 and 2). The Station E, where the ants did not become established, had extremely lower organic material and moisture contents than the natural habitat and other stations where the ants had become established (Table 1). The soil of the Station $\mathrm{E}$ is also characteristic in the relatively

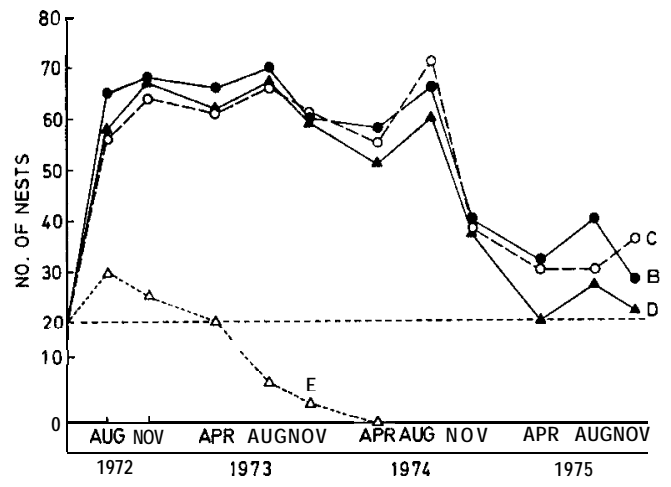

Fig. 1. Annual sequence of nest number in four experimental stations (B, C, D and E) of the first colonization test. Twenty nests were transplanted in each station on May 20, 1972. The number of nests established was counted on 20 of April, August and November. 


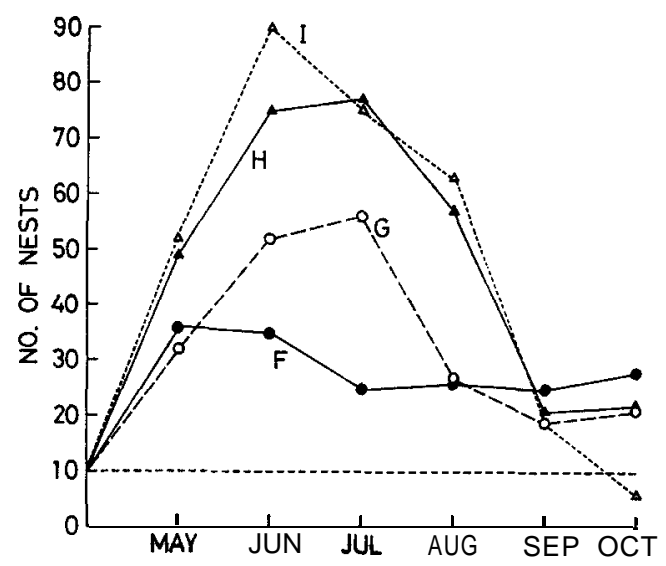

Fig. 2. Seasonal sequence of nest number in four experimental stations (F, G. H and I) of the second colonization test. Ten nests were transplanted in each station on May 2. 1977. The number of nests established was counted on every 30 from May to October.

high ratio of coarse sand and low clay content (Table 2).

The results of the second experiment are shown in Fig. 2. The number of nests in all the stations increased by three to five times in May, and in Stations G, $\mathrm{H}$ and $\mathrm{I}$ it continued increase till June to July by five to nine times, then the majority of these nest sites was abandoned and formed 6 to 22 nests in October. Only in Station F, the number of nests did not much increase, and it was maintained at approximately 30 during the season. The number of nests established in October was much more than other stations, because in this forest stand the ants had formerly inhabited but were exterminated and inhibited by artificial cause 10 or more years previously as mentioned before. By contrast, the nests increased in number tremendously during first two months in Station I (90 small nests in June), then it decreased to only 6 nests in October. The soil of this station is characteristic in the relatively low moisture content (16\% at $0-10 \mathrm{~cm}$ depth) as shown in Table 1.

In the first introduction of F.lugubris from Italy to Canada, the ant population was released around six stumps at a distance of approximately $50 \mathrm{~m}$ separated with each stump in early June, 1971. After 3 or 4 days, however, these sites were completely abandoned, and about 35 small nests were formed over an area of approximately 3 ha. By the end of September most had regrouped into five large nests (Finnegan, 1974). Thus nests in forests where ants were newly introduced sometimes increase in number within a few months after release, but most nests were abandoned and they re-grouped into a few larger nests afterwards.

The results of the transplantation of $F$. yessensis colonies mentioned above showed that the ant easily established in forests growing 10 to 20-year-old red pine trees at a relatively high density but admitting sunlight to the forest floor, harbouring much bare grounds and long graminaceous grasses. The 
ant favours soils with much organic material and rather high moisture content but not wet excessively. Careful consideration must be given to these environmental requirements before an attempt is made to artificially establish ant colonies in a forest.

\section{ACKNOWLEDGEMENTS}

The authors wish to thank Professor Y. Hirashima for his constant guidance. Thanks are also due to $\mathrm{Mr}$. Bu Gun Jeung of Gyeongsang National University for his kind cooperation in the field experiments, Professor Woo Churl Park of the University and Mr. Han Saeng Lee of Research Bureau, Office of Rural Development, Gyeongnam Province for their help in soil analyses, Professor Sam Sik Kim of Gyeongsang National University for his kindness in identification of plants. The authors also thank Professor K. Wada of Kyushu University for his suggestions on soil texture, and Dr. R, J. Finnegan of Laurentian Forest Research Centre, Canada for his kindness in reading the manuscript presented at the XVI International Congress of Entomology which includes the present paper, and giving helpful suggestions. Finally, the senior author thanks Dr. Tae Gyu Yoon, the ex-President of Gyeongsang National University, for his help promoting the present study and encouragement.

\section{REFERENCES}

Adlung, K. G. 1966 A critical evaluation of the European research on use of red wood ants (Formica rufa group) for the protection of forests against harmful insects. $Z$. angew. Ent., 51: 167-189

Finnegan, R. J. 1974 Ants as predators of forest pests. Entomophaga, Mém. H. S., 7:5359

Finnegan, R. J. 1975 Introduction of a predacious red wood ant, Formica lugubris (Hymenoptera: Formicidae), from Italy to eastern Canada. Canad. Ent., 107: 1'271-1274

Ito. M. 1973 Seasonal population trends and nest structure in a polydomous ant, Formica (Formica) yessensis Forel. J. Fac. Sci., Hokkaido Univ., Ser. VI. Zool., 19: 270-293

Kim, C. H. and Y. Murakami 1980a Ecological studies on Formica yessensis Forel, with special reference to its effectiveness as a biological control agent of the pine caterpillar moth in Korea I. Geographical and ecological distributions of Formica yessensis Fore1 (Hymenoptera: Formicidae). J. Fac. Agr., Kyushu Univ., 24: 239-245

Kim, C. H. and Y. Murakami 1980 b Ecological studies on Formica yessensis Forel, with special reference to its effectiveness as a biological control agent of the pine caterpillar moth in Korea II. Bionomics of Formica yessensis Fore1 (Hymenoptera: Formicidae) in Korea. J. Fac. Agr., Kyushu Univ., 25: 119-133

Kim. C. H. and Y. Murakami 1981 Ecological studies on Formica yessensis Forel, with special reference to its effectiveness as a biological control agent of the pine caterpillar moth in Korea III. Nest distribution and environmental conditions of nest sites. J.Fac. Agr., Kyushu Univ., 26: 9-19 